\title{
Application Of The Proportionality
}

\section{Principle In The Credit Restructuring Policy \\ For The The SMEs Financial Performance} During The Covid-19 Pandemic In Indonesia

\author{
Kukuh Tejomurti ${ }^{1}$; Nurhidayatuloh ${ }^{2}$; Irawati Handayani $^{3}$ \\ ${ }^{1}$ Faculty of Law Universitas Sebelas Maret; ${ }^{2}$ Faculty of Law Universitas Sriwijaya; ${ }^{3}$ Faculty of Law Universitas \\ Padjadjaran \\ E-mail: kukuhmurtifhuns@staff.uns.ac.id
}

\begin{abstract}
This article aimed to analyze how to apply the fundamental principle of proportionality in the restructuring of credit contracts to stabilize economic growth in Indonesia during the Covid-19 pandemic period. The spread of Covid-19 directly or indirectly affects debtors' output and ability, including small and medium-sized enterprises (SMEs). This potentially disrupts the efficiency of the banking system and the stability of the financial system which can affect economic growth. Hence, promoting the optimization of the banking intermediation feature, maintaining stability of the financial system, and supporting SMEs' economic growth required economic stimulus policy as Covid-19's countercyclical effect deployment. This research in this study uses the normative legal research. It involves the study of the law as an object and removes any non-legal material from the scope of this research. The findings showed that Credit restructuring for SMEs can help banks to suppress the growth rate of bad credit affected by the spread of Covid-19. Practically the implementation of the restructuring of contract credit as "a suggestion" and not as obligation that must be obeyed by financial service companies so the policy is in favor of the interests of entrepreneurs or investors and does not protect the interests of people who experience the economic impact of Covid-19.
\end{abstract}

Keywords- Covid-19; Credit Contract; Restructuring

\section{INTRODUCTION}

Indonesian society has been facing a "economic storm" due to the Covid-19 pandemic for more that seven months. Almost sectors of micro, small and medium-sized enterprises ( SMEs) are disrupted from this situation by the stability of their industry, even until the bankruptcy faced by the economic turmoil in the Covid-19 pandemic. According to data compiled by the Ministry of Cooperatives and Small Enterprises, there are 185,184 SMEs enterprises are affected by a pandemic that affects small and medium-sized enterprises such as drastically reduced product demand / sales, capital difficulties, difficulties with raw materials and barriers to distribution [1]. The effects contributed to the decrease of national gross domestic product ( GDP) and rising a lot of unemployment at a productive period. Based on data from the Administrating Agency of the Ministry of Manpower and Social Security, approximately 2.8 million employees have been affected by the Covid-19 pandemic due to the cessation of company activities [2]. SMEs has roles to sustain a economic growth that is important to push the economy that has been affected by Covid-19. The Government is also trying to withstand Covid-19 's rate of spread with various recovery efforts. These efforts are providing a relaxing stimulus for debtor banking loans.

The Government has released the National Economic Stimulus Policy (SPN), through the Financial Services Authority ( OJK). This strategy spread as a countercyclical effect on Covid-19 [3] as an attempt to improve the resilience of SMES impacted by Covid-19. SMES debtor can acquire a chance with restructuring to preserve its market stability and the bank can actively assist debtors to stabilize finance [4]. Based on information given by the Financial Services Authority, there are 88 banks that have adopted the restructuring policy with 3,88 million debtors whose value amounts to Rp 336,97 trillion and the remainder are Rp 167,1 trillion SMES loans from 3,47 million debtors [5]. Restructuring credit guarantees against debtors to SMEs is not automatic. They must submit an application in accordance with each bank / related 
financial institution 's mechanisms. Credit / financing is given to a limit of 10 billion rupiahs. Existing debtors like the debtors of two / fourwheeled motor vehicles, improved credit / breeding standard for the Lancer after restructuring. Technical implementation of restructuring with the prudence principle submitted to the Bank / leasing. The longest period / maximum of one year and is a smoothly impacted debtor and credit until the Government declares the Covid-19 emergency. The method of restructuring involves a decrease in interest rates, time extension, reduction in big arrears, Small tax arrears. Then attaching credit / financing services or credit / financing to temporary capital inclusion [6]. In implementation it depends on the bank and relies on the outcome of the bank assessment of the financial performance or evaluation of the market prospects of the debtor and the willingness to pay SMES impacted by Covid-19. A restructuring period varies with a maximum period of one year, based on the bank 's valuation of debtors. So to get a restructuring facility, SMES debtor must submit a restructuring application to the bank where the credit submission [7]. Based on Ministry of Cooperatives and SMES results, it shows that Bank Rakyat Indonesia (BRI) is a bank that has undertaken the most restructuring of credit to SMEs. BRI Bank has a restructured number of SMES debtors with a cumulative loan of Rp 14.9 trillion touching 134.258. Bank Mandiri 's position with 10,592 debtors and total lending was Rp 4.1 trillion. The Bank Tabungan Negara (BTN) third position, with a debtor value of 17,481 Rp 2.7 trillion [8]. Implementing the restructurization credit is a debtor that proposes that credit must fulfill its achievements. Debtor's accomplishment to the borrower in the form of interest payment with deposit, payment date, payment period and credit maturity duration as stipulated in the credit agreement negotiated by the parties. Based on credit contracts, lenders generally have an obligation to provide debtor customers with credit facilities and adequate information, and are entitled to accept payment consisting of accumulation of principal installments, interest or fines if the expiry time is due. The debtor is obliged to make minimum payments and to provide the creditors with assurance. The debtor have the right to access appropriate credit facilities and information on the credit facilities, such as payment forms, accounting sheets. Implementing the debtor 's achievement to the creditors in the form of payment of the creditor's (bank's) liability for credit will cause the credit to be smooth, while in the event of cruelty then this is what causes the problem. If the volume of distressed credit has surpassed the capacity of the bank, it can be turned into a catastrophe, because not only the bank's profitability will be affected, but the liquidity will be at risk. When the issue of credit is tackled, then one of the attempts that can be made is to restructure credit. Credit restructuring can only be done on the basis of written application by the customer with the credit quality category is not smooth, doubtful and jammed as in the condition of pandemic Covid-19 where SMES debtors suffer many problems because demand for products / sales dropped drastically, capital difficulties, raw material difficulties and distribution barriers. Within this article the author will investigate the fundamental application of proportionality principle within credit restructuring in order to stabilize the economic development of Indonesia during the Covid-19 pandemic. The principle of proportionality goes to the root of the law the essence of which is the balancing of competing rights and interests.

\section{RESEARCH METHODS}

This study is a normative legal research that is prescriptive in nature by order to describe application of proportionality principle in the restructuring of the credit contracts for the stabilization of Indonesia's economic growth during the Covid-19 pandemic. The collection of data is carried out through library research to find secondary data using primary, secondary, and tertiary legal materials [9]. The analysis starts from data collection, this data is then presented by means of selecting, classifying systematically, logically and juridically to find out the specific description related to the problems in the research, the authors compare with the theory and concepts of secondary data consisting of scientific books, journals, and related legislation and legal opinions from legal experts. 


\section{DISCUSSION}

A. Restructuring the credit contract as a financial aid for small and medium-sized enterprises ( SMEs).

Covid-19 spread and affect directly or indirectly to debtor output and efficiency, including debtor to SMEs, thus potentially disrupting banking performance and stabilizing the financial system that may affect economic growth. Therefore, to encourage the optimisation of the banking intermediation role, to preserve the stability of the financial system and to support the economic growth of the economic stimulus policy needed as a countercyclical impact of the Covid-19 deployment.

The provisions of the credit restructuring apply the regulations of the banking sector legislation, Bank Indonesia Regulation No. 14/15 / PBI/2012, and POJK Regulation No. 11 of 2020 on national economic stimulus founded that the Bank had to have written credit restructuring policies and procedures in place. To retain objectivity, credit adjustment must be done by officials or officers who are not interested in restructured credit awarding. The strategy in determining credit restructuring is tailored according to each bank's internal policy. Restructuring is carried out in the ongoing willingness to pay and good faith from debtor restructuring credit can be obtained. As with credit application, a proposal for restructuring must be a debtor's initiative. Research has to be performed to determine approval of this reform. Team Leader Credit is working on finding a potential financial restructuring solution. The debtor submits the letter of payment to the management so that the credit is to be made. The restructuring process is analyzed. Team Leader Credit is working on finding a potential financial restructuring solution. The debtor submits the letter of payment to the management so that the credit is to be made. Review of this turnaround process is undertaken to save distressed credit in more detail.
The banking operations are carried out under the principles of prudential banking. On that basis, financial considerations alone are not adequate to offer certainty that the credit facility will return safely and profitably. In the world of troubled credit settlement banking in an atmosphere of credit administration, one effort is made to preserve credit quality. Credit restructuring in bailing out troubled loans is an effort offered and beneficial to both creditors and debtors. Credit restrukrization policy during the Covid-19 pandemic Under OJK Regulation No. 11 year 2020, restructuring of credit / financing was decided as follows:

a. Decrease in interest rate;

b. Extension of time period;

c. reduced principal arrears;

d. Reduction in arrears;

e. Addition of credit/financing facilities; and/or

f. Credit/Financing conversion into temporary capital inclusion;

The policy is addressed to debtors affected by the Covid-19, including SMES, who are debtors who have a hardship to fulfill their obligations because the business of debtors is affected directly or indirectly by the spread of Covid-19 such as the finance, tourism, transport, hospitality, exchange, manufacturing, agricultural and mining sectors. The Covid-19 pandemic stimulus policy consists of

1. Assessment of the quality of credit/financing/provision of funds based on the accuracy of principal payment and/or interest for credit/financing/provision of other funds with a ceiling of $\mathrm{Rp} 10$ billion;

2. Improved credit/financing quality became smooth after restructuring during the validity period of POJK. The provisions of this restructuring can be applied to the Bank without looking at the credit/financing ceiling limitation or debtor type.

Application of restructuring in financial institutions, both banks and nonbanks, is confronted with the submission that may be refused. The government will 
provide the stimulus in the form of loans to the bank which is then channeled to the debtor with a debtor-given magnitude of relaxation. Risks which banks will face, including operational risk, credit risk, , liquidity risk, and market risk [10]. Among these risks, credit risk has a greater impact than other risks. Some of the Bank's practices include: three restructuring forms have been done by the $B A N K D K I$, namely the suspension of the principal of the loan, the decrease in interest rates and the addition of tenor. Bank Mandiri is accelerating the process of credit contract restructuring with the goal of enhancing and speeding up the collectibility cycle. The banks do not feel the effect of the pandemic in the first quarter ( Q1) but many lenders customers began paying the credit in the second quarter. While BRI Bank has four credit contract restructuring schemes for SMEs, such as:

1. The first scheme for debtor that has decreased turnover by $30 \%$, there will be a restructuring contract in the form of decrease in interest rate and tenor renewal;

2. The second scheme for debtors who have decreased turnover more than $30 \%$ up to $50 \%$ will be applied restructuring in the form of delayed interest payments and principal installments for six months;

3. The third scheme for debtors who have decreased turnover of more than $50 \%$ up to $75 \%$, then apply for credit contract restruturisation in the form of delay in payment for 3 six months and delay of principal instalment for 12 months

4. The fourth scheme for debtor who have decreased turnover more than $75 \%$ will be applied restructuring in the form of delayed interest payment for twelve months and delay of principal instalment;

The Financial Services Authority gives the borrower the trust to enforce a strategy imposed by Financial Services Authority legislation, and the implementation of restructuring for each debtor varies depending on the debtor's credit risk and depends on the bank's strategy and analysis itself. The underlying restructuring strategy of this credit contract is not to release loans, but rather to postpone payments. The bank must experience liquidity and income pressures for unpaid payments, so that interest subsidy is received by the government.

\section{B. Principle of Proportionality in Implementation of Credit Contract Restructuring}

In credit contracts involving small and medium-sized businesses and other major corporations typically resulted from conflicts of interest which were attempted to be reunited via contracts. The disparity is accommodated, and then framed by a legal mechanism in order to bind the parties. The problem of the side of certainty and fairness can be resolved in a credit contract when the discrepancies between the parties are influenced by the structures of contractual relations that operate proportionately [11]. Inside a credit contract it is important to analyze carefully so that the contractual provisions are not immediately considered unbalanced as it reads only the grammatical text of the contract material.

A fair contract shall be the creation of a credit contract based on the exchange of the Parties' rights and obligations. It is possible to analyze the proportionality of rights and obligations from the content of the contractual agreements negotiated between the parties. The proportionality of the exchange of rights and obligations will be measured on the basis of rational reasoning, not the suspicion and subjectivity of one party against another. According to Richard J. Conviser, the importance of the proportionality principle with respect to the content of the principle of proportionality is according to the average; proportionate to any average to standard; proportionate. This is modeled in its implementation: An insolvent can have his assets "pro rata" divided among his creditors, meaning that each will receive payment in equal proportion to what he is owned [12]. Agus Yudha Hernoko argues that in concisely the principle of proportionality as a division of 
rights and obligations according to the proportion that encompasses all aspects of overall contractual.

Implementation of a credit contract at the Covid-19 pandemic was reviewed from the perspective of the principle of proportionality that restructuring contracts for having to see real conditions affecting the implementation of credit contracts can not be enforced by all loan contracts. It is necessary to apply the principle of proportionality in stabilizing economic growth stability, so as not to trigger economic crisis. There is no restriction in the implementation of the concept of proportionality for one contracting party. (e.g. banks) to protect its interests from being harmed, while the other (e.g. debtor) can also renegotiate to protect its interests on the condition of no harm each other [13]. In the case of investors (banks) they need to protect their interests as the bank controls the funds raised from the community so that when the funds are channeled in the form of credit to the community. The Bank will make every effort to preserve banking prudential and preserve community trust. In the debtor sense, a fairness in Covid-19's pandemic circumstances has endured a lot of difficulties in making the achievement of potentially unwanted default, and this is fairness and justice for the debtor to be able to renegotiate in the form of credit settlement contracts.

Making a new theory of the obstacles to contract execution that is relevant enough to be considered is theory of hardship. It is special in the case of Overmacht and is set by the Civil Law Code. The term hardship defined as difficult state, while on various legal systems used the term: frustation of Purpose, Wegfall der Geschaftgrundlage, (UPICC Article 6.2.1. Hardship determines that if the implementation of the contract becomes heavier for either party, the party may be subject to provisions on hardship. It is governed by article 6.2.1 UPICC of contract to be observed. These terms define the two main points, such as [14]:

1. The binding nature of the contract as a general rule;

2. Changes in relevant circumstances only related to certain contracts;
Article 6.2.2 on the definition of hardship includes a description of hardship in the event that the balance of contracts incurred by the expense of executing contracts has dramatically changed to substantially increase the burden on the contracting party (debtor) or the value of executing the contract to be drastically decreased for the receiver (creditor), and

1. The event occurred or was known by the party harmed after the closure of the contract;

2. The event cannot be reasonably foreseeable by the injured party at the conclusion of the contract;

3. The event occurs outside the control of the harmed party;

4. The risk of the event was not suspected by the injured party;

For developed countries, such as the Netherlands, Germany and France, a more versatile provision has been made to form the basis of forgiving (excuse) for the enforcement of the Agreement based on the concept of circumstances adjustment or hardship. Though there is no agreement in Indonesia on the theory of shifting circumstances or difficult situations, Nevertheless, it is also possible to renegotiate the contracts due to the outbreak of the Covid-19 which became a national catastrophe. It is due to the parties' duty to implement the Agreement on the basis of goodwill values as stipulated in Article 1338(3) of civil law. Goodwill principle requires a fair and equitable arrangement to be applied (reasonableness and equity).

Thus, it will not be feasible and appropriate if the agreement is still prosecuted in the event of a change in circumstances or difficult circumstances so that it is strongly incriminated by one party to the agreement [15]. The harmed party reserves the right to require adjustment of the contractual terms or agreements to conform to new circumstances [16].

Research shows that the credit contract restructuring has four problems as follows: 
First, the credit contract restructuring policy only accommodates banking financial services. Such as Conventional Commercial Banks, Sharia Commercial Banks, Sharia Business Units, People's Credit Banks, and Sharia Rural Banks. Practically, the decline in the ability to pay credit is not only experienced by banking customers, but also users of other financial services such as leasing companies and online loans. The government should evaluate these regulations.

Second, some banks only agree to relax credit for debtors who are patients under monitoring or positive patients with Covid-19. Many debtors have accepted credit restructuring refusals because they were not directly affected by Covid-19. In fact, his work and business experienced a decline in income and was on the verge of bankruptcy. Based on the considerations in POJK Number 11 of 2020, it states, "The development of the spread of coronavirus disease 2019 (Covid-19) globally has had a direct or indirect impact on the performance and capacity of debtors in fulfilling credit or financing payment obligations."

Third, practically credit relaxation can only be done if the bank approves the loan relaxation application. As a result, many debtors are unable to relax their loans because they are not approved by the bank. The author argues that interpreting this policy only as "advice", not "obligation" that must be obeyed [17]. As a result, the policy is in favor of the interests of entrepreneurs or investors and does not protect the interests of people who experience the economic impact of Covid-19.

Fourth, there is no supervisory mechanism created by Financial Service Authority if credit relaxation (for credit restructuring) is refused, even though it meets the requirements as stipulated in POJK Number 11 of 2020 mentioning that debtors who can apply for credit relaxation must meet 2 conditions [18]. First, the debtor with the highest ceiling of Rp10 billion and good credit quality since the implementation of the restructuring agreement.

If it meets these requirements, the Bank should grant the request for credit relaxation. However, practically some Banks set additional requirements that could be reasons for refusing credit relaxation so that the structuring policy does not apply the proportionality principle.

\section{CONCLUSION}

There is no limitation in the principle of proportionality for any party negotiating (e.g. banks) to protect their interests from harm, whereas others (e.g. borrowers) can also renegotiate to protect their interests on condition that they are not mutually harmful.

The presence of government policy to resolve the Covid-19 outbreak, the application of the agreement achievement can also be enforced to keep it from coming into effect as a significant category. Nevertheless it is not necessary to pursue the enforcement of the Agreement without changing the terms of the Agreement. The parties then ought and renegotiate and change the terms of the agreement to the current conditions, so as not to damage one party to the agreement. The repayment of the loan must be rescheduled in the form of restructuring the loan contracts against the Covid19 pandemic impacted parties such as: major social restrictions.

\section{REFERENCES}

[1] Supomo. Cooperative E-Learning, Edisi No.03, Mei 2020. Kementerian Koperasi dan UKM Republik Indonesia. p.12, 2020

[2] Kementerian Ketenagakerjaan. "Pemerintah Antisipasi Penambahan Pengangguran di masa Pandemi Covid-19" [Online] Available: pemerintah-antisipasi-penambahanpengangguran-di-masa-pandemi-covid-19, on https://kemnaker.go.id/news/detail/pemerintah -antisipasi-penambahan-pengangguran-dimasa-pandemi-covid-19. [Accessed 17 August -2020]

[3] E. Satria. Ready For Future,Bank BTPN A Member of SMBC Group, 2020.

[4] R. Baldwin. Economics in the Time of Covid-19. London UK: CERP Press, 2020 
[5] S. P. Djarot. Pengumuman Restrukturisasi/Keringanan Bagi Debitur Perbankan dan Perusahaan Pembiayaan Yang Terkena Dampak Covid-19. Jakarta: OJK Update, 2020.

[6] UNCTAD. From the Great Lockdown to the Great Meltdown: Developing Country Debt in the Time of Covid-19, UN Trade and Development Report Update: Geneva, 2020.

[7] P. Trisna Dewi, "Implementasi Ketentuan Restrukturisasi Kredit Terhadap Debitur Wanprestasi Pada Kredit Perbankan", Jurnal Magister Hukum Udayana (Udayana Master Law Journal), vol. 4, no. 2, 2015.

[8] Sutarmo. Relaksasi Kredit Bagi Koperasi dan UMKM, Cooperative E-Learning, Edisi No.03, Mei 2020, Kementerian Koperasi dan UKM Republik Indonesia, 2020.

[9] P. M. Marzuki. Penelitian Hukum. Jakarta: Prenada Media, 2003.

[10] J. Ang, J. Chua And J. Mcconnell, "The Administrative Costs of Corporate Bankruptcy: A Note", The Journal of Finance, vol. 37, no. 1, pp. 219-226, 1982.

[11] A.Y Hernoko. Hukum Perjanjian: Asas Proporsionalitas Dalam Kontrak Komersial. Jakarta, Pena Grafika. 2010.

[12] S. Gilson, K. John and L. Lang, "Troubled debt restructurings", Journal of Financial Economics, vol. 27, no. 2, pp. 315-353, 1990.
[13] K. Tejomurti. Pertanggungjawaban Hukum yang Berkeadilan terhadap Aparatur Pemerintah pada Kasus Pengadaang Barang dan Jasa. Dialogia Iuridica: Jurnal Hukum Bisnis dan Investasi, Vol. 8, No. 2., pp. 42-52, 2017.

[14] (UNIDROIT Principles of International Commercial Contracts

[15] A.B Cahyono, Keppres 12/2020 Sebagai Dalil Force Majeure, Benarkah?, [Online] Available:

https://www.hukumonline.com/berita/baca/lt5 e9fe7fdle34d/keppres-12-2020-sebagai-daliliforce-majeure-i--benarkah-oleh--akhmadbudi-cahyono/, [Accessed 18-August-2020]

[16] L. Hanim and M. Noorman, "Penyelesaian Perjanjian Kredit Bank Sebagai Akibatforce Majeure Karena Gempa Di Yogyakarta", Jurnal Pembaharuan Hukum, vol. 3, no. 2, p. 161, 2016.

[17] C. Cauffman, "The Principle of Proportionality and European Contract Law", Rules and Principles in European Contract Law, pp. 69-98.

[18] A. Shomad, "Financing Risks Of Micro, Small, And Medium Enterprises (Umkm) With Cooperation Patterns Between Islamic Bank And Baitul Maal Wa Tamwil (Bmt)", Jurnal Dinamika Hukum, vol. 17, no. 1, p. 53, 2017. 